there being now a swamp to windward; also, as in Florida, there may be outlying keys, or, as at many places, beach ridges, the keys or beach ridges being higher than the swamp and consequently higher than the old beach or sandy expanse from which the dune grew.

Evidently, such quiescent dunes furnish positive evidence of a rise of sea level. Also, it is clear that this change of sea level must be of Recent or of latest Pleistocene age, the position of the dividing line between Pleistocene and Recent time being necessarily a matter of opinion, for the dunes can not be old. Even those of Florida, which indicate a rise of sea level of at least five or six feet at their bases, rest on late Pleistocene marls and limestone. The exact age of the dunes and the exact length of time that has elapsed since they became quiescent by the growth of swamps cutting off supplies of sand, are alike indeterminable, but the sharpness of characteristic outlines and the size of the trees on many of them indicate quiescence for hundreds, but not for thousands of years.

A locality where this relation between swamp growth and dune quiescence may be conveniently observed by many persons is at Ventnor, N. J., on Absecon Island, south of Atlantic City.

It is believed that the evidence of the dunes mentioned confirms that of shore-lines, beach ridges, and coastal swamps, namely, that the Atlantic coast of the United States has subsided, or the sea level has risen, in Recent time, and that the change of sea level is probably still in progress.

Evidently, also, termination or interruption of growth by a near-by rise of water level is not restricted to dunes along the sea shore, but applies to all dunes.

WASHINGTON, D. C.,

December 20, 1915

\section{A REPUTED SPECIFIC FOR BLACKWATER} FEVER

I HAVE in my herbarium two curious plants from the interior of Venezuela, which are of special interest because of their chemical properties. They were collected and presented to me by Dr. Jesus Maria Piñango at Guanoco, Venezuela.

The first specimen is used by the natives of eastern Venezuela as a specific for the dreaded blackwater fever. The plant grows in swamps and reaches a height of six feet. It bears ovate, opposite, entire leaves, tapering to a long point. When boiled to use for fever it colors the water rose-pink.

I should like to invite any reader of SoIENCE who is an expert in therapeutics, and would be interested to analyze and test the properties of this plant to communicate with me, and I will gladly send a specimen for this purpose. For if this plant really possesses the medicinal properties ascribed to it, it might be of much value in the treatment of the blackwater fever, which is so fatal in parts of Venezuela and still more prevalent and deadly in tropical Africa.

The other specimen is a very powerful narcotic. It is called by the Guarauno Indians Charapu; and is used by them for poisoning fish in the following manner. A quantity of the leaves are gathered and pounded down into a small hole in the ground so as to form a ball. This is then dried. On going fishing in a river or stream, one man takes this ball of leaves, dips it in the water and rubs it in his hands like a cake of soap. The rest of the party, with scoops and baskets, stand a short distance down stream. Almost immediately the fish become locoed, rise to the surface, swim wildly in circles, then become insensible, and are easily secured and gathered into the baskets, so powerful is the narcotic principle of the Charapu.

\section{Carlotta Joaquina Maury}

\section{UNIVERSITY REGISTRATION STATISTICS}

To THE Editor of ScIence: In the case of Washington University, the comparison of the University Registration statistics published in ScIEnce, January 21, 1916, with those published for the year preceding, shows a loss in the total number of students in that institution. Actually, Washington University had an increase; 174 in the degree conferring departments alone. This apparent loss is due to a change in the classification of a certain 